varicose veins in the 27 normal legs had risen from $44 \%$ to $55 \%$ (see table II). The type of new varicose veins that developed is shown in table III. If the ankle flare is accepted as a sign of perforator vein incompetence then six of the eight F.U.T.-positive and previously normal legs which developed new varicose veins had evidence of perforator vein incompetence, compared with two of the three legs in the negative result group, an insignificant difference. None of the varicose veins that were present at the time of the thrombosis got significantly worse.

Doppler Ultrasound Examination.-In none of the patients was there any clinical evidence of further thrombosis of the major veins above the knee. Of the 88 legs 56 were examined with the Doppler flow detector and all had normal flow patterns.

Pulmonary Embolism.-No patients had had any symptoms suggestive of pulmonary embolism between their discharge from hospital and the follow-up examination.

\section{Discussion}

Our general impression after reviewing these patients was that there was no disabling late morbidity that could be attributed to the thrombosis. We were surprised, however, that many of the minor symptoms had persisted for so long. The initial incidence of aohes and pains in the limbs in which the F.U.T. gave positive results was $34 \%$, compared to $4 \%$ in the normal limbs. As pain was not present before the thrombosis, with the exception of the pain in the one F.U.T.-negative leg, it is reasonable to attribute it to the thrombosis. The followup showed that one-half of the patients who had pain at the time of their thrombosis still had some discomfort three years later, and a few painless legs had become painful. Though this was a mild symptom some of our patients found it extremely annoying.

Swelling of the ankle also persisted in three quarters of the legs that were swollen at the time of the thrombosis. New swelling appeared in equal proportions in the thrombosed and normal legs. As it is difficult to exclude all other causes of swelling it would be wrong to attribute all cases of ankle swel- ling to the thrombosis. Nevertheless, there was little doubt that the swelling was due to the thrombosis in some of the younger patients and that it persisted for three years.

The high incidence of varicose veins in our patients was probably due to the fact that they were an elderly group and we classified any tortuous, subcutaneous dilated vein as a varicose vein. The incidence of new varicose veins was the same in the legs which had been thrombosed as the legs that had been normal so nothing in our data suggests that the small F.U.T.-detected thrombus damages the perforating veins and predisposes to the postphlebitic leg. Interestingly, most of the new veins that developed in both the F.U.T.-negative and the F.U.T.-positive legs were of the type associated with perforator vein incompetence. As neither group had any episodes between the time of the thrombosis and the follow up examination suggestive of further thrombosis the cause of these new veins remains unexplained.

We conclude that though the minor form of deep vein thrombosis, which is a common complication of all operations and illnesses, is not a serious condition it can cause long-lasting symptoms. If the calf aches at the time of the thrombosis it is likely that it will continue to ache for at least three years. This is a minor symptom, and the patients that we interviewed had come to accept it. Nevertheless, the fact that it did persist suggests that the fibrinogen detectable thrombus is not an entirely benign condition and may disturb the physiology of the peripheral veins. We have no evidence to suggest, however, that the physiological disturbance is sufficient to cause varicose veins. We do not think that the persisting symptoms we have described are severe enough to justify treating the initial thrombosis with anticoagulants because such treatment is probably far more dangerous than the symptoms, but it may be worthwhile preventing these thrombi with a safe form of prophylaxis.

\section{References}

Atkins, P., and Hawkins L. A. (1965). Lancet, 2, 1216.

Flanc C., Kakkar, V. V., and Clarke M. B. (1968). British fournal of Surgery, 55,742 .

Negus, D., Pinto, D., Le Quesne, L., Brown, N., and Chapman, M. (1968). British fournal of Surgery, 55, 835 .

\title{
Interaction between Doxycycline and some Antiepileptic Drugs
}

\author{
O. PENTTILÅ, P. J. NEUVONEN， K. AHO， R. LEHTOVAARA
}

British Medical fournal, 1974, 2, 470-472

\section{Summary}

The mean half life of doxycycline given to seven patients on long-term diphenylhydantoin treatment was $7 \cdot 2 \pm 0.4$ hours. In five patients on long-term carbamazepine treatment the

\section{Maria Hospital, Helsinki, Finland}

O. PENTTILA, M.D., Consultant Physician in Medicine and Clinical Pharmacology

Department of Clinical Pharmacology, University of Helsinki, Finland

P. J. NEUVONEN, M.D., Assistant Professor

Pitäjänmäki Epilepsy Research Centre, Helsinki, Finland

K. AHO, M.D., Consultant Physician in Neurology

R. LEHTOVAARA, M.D., Consultant Physician in Neurology half life was $8.4 \pm 1.4$ hours. In four patients on combined diphenylhydantoin and carbamazepine treatment the half life was $7.4 \pm 0.7$ hours. All these were significantly shorter than a mean half life of $15.1 \pm 1.0$ hours when doxycycline was given to nine control patients. Therefore doxycycline in normal doses given to patients taking diphenylhydantoin or carbamazepine may fail to maintain the minimum inhibitory concentration necessary for proper bacteriostasis. When doxycycline is given in association with agents known to induce drug metabolism the serum concentration of the antibiotic should be watched to see that bacteriostatic levels are maintained.

\section{Introduction}

Treatment with a bacteriostatic antibiotic is ineffectual unless its serum concentration is continuously maintained at or above the minimum inhibitory level. Doxycycline seems to 
TABLE III-Half Life of Doxycycline in Patients on Long-term Combined iphenylhydantoin and Carbamazepine Therapy

\begin{tabular}{|c|c|c|c|c|c|c|c|c|c|}
\hline \multirow[b]{2}{*}{ Case No. } & \multirow[b]{2}{*}{ Sex and Age } & \multirow[b]{2}{*}{ Weight (kg) } & \multicolumn{2}{|c|}{ Daily Dose (mg) } & \multicolumn{2}{|c|}{ Duration of Therapy } & \multicolumn{2}{|c|}{ Serum Concentration $(\mu \mathrm{g} / \mathrm{ml})$} & \multirow{2}{*}{$\begin{array}{l}\text { Half Life of } \\
\text { Doxycycline } \\
\text { (Hours) }\end{array}$} \\
\hline & & & $\begin{array}{l}\text { Carbam- } \\
\text { azepine }\end{array}$ & $\begin{array}{l}\text { Diphenyl- } \\
\text { hydantoin }\end{array}$ & $\begin{array}{l}\text { Carbam- } \\
\text { azepine }\end{array}$ & $\begin{array}{l}\text { Diphenyl- } \\
\text { hydantoin }\end{array}$ & $\begin{array}{l}\text { Carbam- } \\
\text { azepine }\end{array}$ & $\begin{array}{l}\text { Diphenyl- } \\
\text { hydantoin }\end{array}$ & \\
\hline $\begin{array}{l}1 \\
2 \\
3 \\
4\end{array}$ & $\begin{array}{l}\text { M. } 27 \\
\text { F. } 20 \\
\text { M. } 20 \\
\text { M. } 42\end{array}$ & $\begin{array}{l}85 \\
60 \\
75 \\
69\end{array}$ & $\begin{array}{l}800 \\
800 \\
600 \\
800\end{array}$ & $\begin{array}{l}300 \\
350 \\
300 \\
300\end{array}$ & $\begin{array}{l}10 \text { Years } \\
9 \text { Months } \\
8 \text { Months } \\
5 \text { Years }\end{array}$ & $\begin{array}{r}4 \text { Months } \\
21 \text { Months } \\
8 \text { Months } \\
16 \text { Months }\end{array}$ & $\begin{array}{l}7 \cdot 6 \\
7 \cdot 2 \\
5 \cdot 1 \\
6 \cdot 1\end{array}$ & $\begin{array}{r}6.0 \\
14.5 \\
5.5 \\
4.5\end{array}$ & $\begin{array}{l}6 \cdot 1 \\
6 \cdot 4 \\
8 \cdot 4 \\
8 \cdot 7\end{array}$ \\
\hline & & & & & \multicolumn{4}{|r|}{ Mean \pm S.E. } & $7 \cdot 4 \pm 0.7$ \\
\hline
\end{tabular}

be eliminated mainly by the liver, since the drug does not accumulate significantly in cases of renal insufficiency (Klinger et al., 1970). Many commonly used drugs stimulate the hepatic metabolism of other drugs (Breckenridge and Orme, 1971; Remmer, 1972; Prescott, 1973) and barbiturates have been shown to shorten the half life of doxycycline in man (Neuvonen and Penttilä, 1974). The present study aimed to discover whether the widely used antiepileptic drugs diphenylhydantoin and carbamazepine had a similar effect.

\section{Patients and Methods}

Sixteen patients suffering from epilepsy, trigeminal neuralgia, or a cardiac arrhythmia volunteered to take part in the study. Seven of the patients had been taking diphenylhydantoin continuously for periods of from four months to 10 years (table I); five had been taking carbamazepine continuously for periods of from four months to four years (table II); and four patients had been taking both diphenvlhydantoin and carbamazepine continuously for longer periods (table III). Two of the patients were currently receiving digoxin and fruseriuic (iables I and II) and a third was receiving digoxin, frusemide, and pericyazine (table $I$ ) in addition to their antiepileptic medication. Otherwise no other drugs were being taken.

Nine other patients who were not taking either diphenylhydantoin or carbamazapine volunteered to act as controls. One patient in the control group was on digoxin and frusemide therapy (table IV).

TABLE I-Half Life of Doxycycline in Patients on Long-term Diphenylhydantoin Therapy

\begin{tabular}{|c|c|c|c|c|c|c|}
\hline $\begin{array}{l}\text { Case } \\
\text { No. }\end{array}$ & $\begin{array}{l}\text { Sex } \\
\text { and } \\
\text { Age }\end{array}$ & $\begin{array}{c}\text { Weight } \\
(\mathrm{kg})\end{array}$ & $\begin{array}{c}\text { Dose of } \\
\text { Diphenyl- } \\
\text { hydantoin } \\
\text { (mg/day) }\end{array}$ & $\begin{array}{c}\text { Duration } \\
\text { of } \\
\text { Therapy }\end{array}$ & $\begin{array}{c}\text { Serum Con- } \\
\text { centration } \\
\text { of Diphenyl- } \\
\text { hydantoin } \\
(\mu \mathrm{g} / \mathrm{ml})\end{array}$ & $\begin{array}{c}\text { Half Life } \\
\text { of Doxy- } \\
\text { cycline } \\
\text { (Hours) }\end{array}$ \\
\hline $\begin{array}{l}1 \\
2 \\
3 \\
4^{*} \\
5 \\
6 \\
7 \dagger\end{array}$ & $\begin{array}{l}\text { F. } 46 \\
\text { F. } 32 \\
\text { M. } 26 \\
\text { F. } 83 \\
\text { M. } 24 \\
\text { M. 46 } \\
\text { F. } 84\end{array}$ & $\begin{array}{l}69 \\
58 \\
72 \\
51 \\
73 \\
75 \\
52\end{array}$ & $\begin{array}{l}200 \\
200 \\
400 \\
200 \\
300 \\
500 \\
200\end{array}$ & $\begin{array}{r}10 \text { Years } \\
6 \text { Years } \\
6 \text { Years } \\
4 \text { Months } \\
6 \text { Months } \\
2 \text { Years } \\
1 \text { Year }\end{array}$ & $\begin{array}{r}4 \cdot 0 \\
6 \cdot 0 \\
11 \cdot 0 \\
8 \cdot 8 \\
7.5 \\
15 \cdot 0 \\
3.3\end{array}$ & $\begin{array}{l}5 \cdot 8 \\
6.5 \\
6 \cdot 6 \\
7 \cdot 1 \\
7 \cdot 3 \\
7.5 \\
9 \cdot 4\end{array}$ \\
\hline & & & & \multicolumn{2}{|c|}{ Mean \pm S.E } & $7 \cdot 2 \pm 0 \cdot 4$ \\
\hline
\end{tabular}

* Also taking digoxin $0.25 \mathrm{mg}$ and frusemide $40 \mathrm{mg}$ daily.

†Also taking digoxin $0.125 \mathrm{mg}$, frusemide $40 \mathrm{mg}$, and pericyazine $12.5 \mathrm{mg}$ daily.

TABLE II-Half Life of Doxycycline in Patients on Long-term Carbamazepine Therapy

\begin{tabular}{|c|c|c|c|c|c|c|}
\hline $\begin{array}{l}\text { Case } \\
\text { No. }\end{array}$ & $\begin{array}{l}\text { Sex } \\
\text { and } \\
\text { Age }\end{array}$ & $\begin{array}{l}\text { Weight } \\
(\mathbf{k g})\end{array}$ & $\begin{array}{l}\text { Dose of } \\
\text { Carbama- } \\
\text { zepine } \\
\text { (mg/day) }\end{array}$ & $\begin{array}{l}\text { Duration } \\
\text { of } \\
\text { Therapy }\end{array}$ & $\begin{array}{c}\text { Serum } \\
\text { Concentra- } \\
\text { tion of } \\
\text { Carbama- } \\
\text { zepine } \\
(\mu \mathrm{g} / \mathrm{ml})\end{array}$ & $\begin{array}{c}\text { Half Life of } \\
\text { Doxycyc- } \\
\text { line } \\
\text { (Hours) }\end{array}$ \\
\hline $\begin{array}{l}1 \\
2 \\
3 \\
4 \\
5 *\end{array}$ & $\begin{array}{l}\text { F. } 30 \\
\text { F. } 25 \\
\text { F. } 36 \\
\text { M. } 18 \\
\text { F. } 76\end{array}$ & $\begin{array}{l}57 \\
42 \\
61 \\
73 \\
73\end{array}$ & $\begin{array}{r}1,000 \\
400 \\
300 \\
1,000 \\
600\end{array}$ & $\begin{array}{l}3 \text { Years } \\
2 \text { Years } \\
2 \text { Years } \\
4 \text { Years } \\
4 \text { Months }\end{array}$ & $\begin{array}{r}11.2 \\
6.1 \\
5.0 \\
10.5 \\
6.5\end{array}$ & $\begin{array}{r}5 \cdot 2 \\
7.0 \\
7.9 \\
8 \cdot 2 \\
13 \cdot 4\end{array}$ \\
\hline & & & & \multicolumn{2}{|c|}{ Mean \pm S.E. } & $8.4 \pm 1.4$ \\
\hline
\end{tabular}

*Also taking digoxin $0.25 \mathrm{mg}$ and frusemide $40 \mathrm{mg}$ daily.
TABLE IV-Half Life of Doxycycline in Control Group of Patients

\begin{tabular}{|c|c|c|c|c|}
\hline $\begin{array}{l}\text { Case } \\
\text { No. }\end{array}$ & Sex & Age & $\begin{array}{c}\text { Weight } \\
(\mathbf{k g})\end{array}$ & $\begin{array}{c}\text { Half Life of } \\
\text { Doxycycline } \\
\text { (Hours) }\end{array}$ \\
\hline $\begin{array}{l}1 \\
2 \\
3 \\
4 \\
5^{*} \\
6 \\
7 \\
8 \\
9\end{array}$ & $\begin{array}{l}\text { F. } \\
\text { M. } \\
\text { F. } \\
\text { F. } \\
\text { M. } \\
\text { F. } \\
\text { M. } \\
\text { M. } \\
\text { F. }\end{array}$ & $\begin{array}{l}30 \\
30 \\
33 \\
25 \\
72 \\
22 \\
48 \\
39 \\
39\end{array}$ & $\begin{array}{l}46 \\
72 \\
57 \\
49 \\
60 \\
6 ? \\
60 \\
63 \\
51\end{array}$ & $\begin{array}{l}10 \cdot 1 \\
11 \cdot 1 \\
14 \cdot 2 \\
14.7 \\
16 \cdot 1 \\
16 \cdot 2 \\
17.5 \\
17.6 \\
18 \cdot 4\end{array}$ \\
\hline \multicolumn{4}{|c|}{ Mean \pm S.E. } & $15 \cdot 1 \pm 1 \cdot 0$ \\
\hline
\end{tabular}

*Also taking digoxin $0.25 \mathrm{mg} /$ day and frusemide $40 \mathrm{mg}$ each other day.

Doxycycline hydrochloride $100 \mathrm{mg}$ (as base) was given intravenously at 08.00 hours to the patients in the study and control groups. Blood samples were taken $3,5,8,12$, and 24 hours later. The serum concentration of doxycycline in each sample was determined both fluorometrically (Kohn, 1961) and microbiologically (Bennett et al., 1966), as previously described (Neuvonen and Penttilä, 1974). Serum concentrations of diphenylhydantoin (Vendelin-Olesen, 1969) and carbamazepine (Frey and Yrjänä, 1970) were determined immediately before and 24 hours after the injection of doxycycline-that is, one to two hours after the antiepileptic drug was taken-and the mean of the two values recorded. Both the serum creatinine and the aspartate aminotransferase levels were normal before the doxycycline injection, as was the aspartate aminotransferase level five days later. The urinary $\mathrm{pH}$ did not differ in the various groups.

\section{Results}

Means with standard errors (S.E.) were calculated and Student's $t$ test was used for statistical evaluation.

The half life of doxycycline in the control group was 15.1 \pm 1.0 hours (table IV). In the patients on long-term diphenylhydantoin treatment the half life of doxycycline was $7 \cdot 2 \pm 0.4$ hours (table I)-significantly shorter $(P<0.001)$ than in the controls-and in the patients on carbamazepine the half life was $8.4 \pm 1.4$ hours (table II), again significantly shonter $(P<0.005)$ than in the controls. The half life of doxycycline in the patients on combined diphenylhydantoin and carbamazepine was $7.4 \pm 0.7$ hours (table III), also significantly shorter $(P<0.001)$ than in the controls. The means of the serum diphenylhydantoin and carbamazepine levels varied considerably according to the dosage and other variables (tables I-III).

\section{Discussion}

The half life of doxycycline vis siuch shortened in nearly all the patients taking diphenylhydantoin or carbamazepine or both together. These antiepileptic drugs are potent agents for inducing drug metabolism (Remmer, 1962; Conney, 1967; Hansen et al., 1971). Induction of drug metabolism is directly related to the dose of the inducing substance and the duration of therapy (Breckenridge et al., 1973). This relation 
may be seen in the duration of antiepileptic therapy in the patients in our study. Displacement of doxycycline from plasma protein by diphenylhydantoin or carbamazepine might to some extent contribute to the increased turnover of doxycycline, but not enough wholly to explain the shortening of the half life we found in our cases.

As well as an antiepileptic drug diphenylhydantoin is also increasingly used as an antiarhythmic drug, and carbamazepine is also given in cases of trigeminal neuralgia. Other antiepileptic drugs such as primidone, methoin, and paramethadione, which also induce drug metabolism (Remmer, 1972), may hasten the metabolism of doxycycline. Sulthiame, on the other hand, interferes with the metabolism of diphenylhydantoin to prolong its half life (Hansen et al., 1968; Richens and Houghton, 1973), so sulthiame is unlikely to indıce doxycycline metabolism.

Whether other tetracycline derivatives are affected in the same way as doxycycline remains to be seen. But when highly lipophilic tetracycline derivatives are given together with diphenylhydantoin or carbamazepine, or other drugs known to be inducers of drug metabolism, the serum tetracycline concentration should be watched to see that it does not fall below the minimum inhibitory level.
We thank the patients who volunteered to take part in this trial, and the nurses for their essential assistance. We are indebted to Pfizer Oy for support and to the National Research Council for Medical Sciences, Finland, for a grant.

\section{References}

Bennett, J. V., Brodie, J. L., Benner, E. J., and Kirby, W. M. M. (1966). Applied Microbiology, 14, 170.

Breckenridge, A., and Orme, M. (1971). Annals of the New York Academy of Sciences, 179, 421.

Breckenridge, A., Orme, M. L'E., Davies, L., Thorgeirsson, S. S., and Davies, D. S . (1973). Clinical Pharmacology and Therapeutics, 14, 514 Conney, A. H. (1967). Pharmacological Reviews, 19, 317.

Frey, H., and Yriänä, T. (1970). Scandinavian fournal of Clinical and Laboratory Investigation, 25, Suppl. No. 113, p. 90.

Hansen, J. M., Kristensen, M., and Skovsted, L. (1968). Epilepsia, 9, 17. Hansen, J. M., Kristensen, M., and Skovsted, L. (1968). Epilepsia, 9, 17. Pharmacology and Therapeutics, 12, 539.

Klinger, W., Bayerl, P., and Edel, H. (1970). In Progress in Antimicrobial and Anticancer Chemotherapy: Proceedings of Sixth International Congress of Chemotherapy, vol. 1 , p. 605, Baltimore, University Park Press.

Kohn, K. W. (1961). Analytical Chemistry, 33, 862

Neuvonen, P. J., and Penttilä, O. (1974). British Medical Fournal, 1, 535.

Prescott, L. F. (1973). Drugs, 5, 161.

Remmer, H. (1962). In Proceedings of First International Pharmacological Meeting, ed. B. Uvnäs, vol. 6, p. 235. Oxford, Pergamon.

Remmer, H. (1972). European fournal of Clinical Pharmacology, 5, 116.

Richens, A., and Houghton, G. W. (1973). Lancet, 2, 442.

Vendelin-Olesen, $\mathrm{O}$. (1969). Scandinavian fournal of Clinical and Laboratory Investigation, 23, 175.

\title{
Comparison of Effect of Two Induction Doses of Metho- hexitone on Infants Delivered by Elective Caesarean Section
}

\author{
ANITA HOLDCROFT, M. J. ROBINSON, H. GORDON, J. G. WHITWAM
}

British Medical fournal, 1974, 2, 472-475

\section{Summary}

Observations were made on 26 infants delivered by elective caesarean section under general anaesthesia. A standard anaesthetic technique was employed using a methohexitone, relaxant, nitrous oxide-oxygen sequence with regulated ventilation and the administration of papaveretum after clamping the umbilical cord. In 12 patients the induction dose of methohexitone was $1.4 \mathrm{mg} / \mathrm{kg}$ and in 14 it was reduced to $1.0 \mathrm{mg} / \mathrm{kg}$. There were no significant differences between the two groups in the clinical status of the mothers, in operative technique and timing, or in the value of $\mathrm{PO}_{2}, \mathrm{PCO}_{2}$, and $\mathrm{pH}$ in the umbilical cord venous blood.

The infants whose mothers received the lower dose of methohexitone were in better condition, as assessed by the number needing assisted ventilation, the time taken to establish regular respiration, the Apgar score, and the "Apgar minus colour" score.

Royal Postgraduate Medical School, London W12 0HS

ANITA HOLDCROFT, M.B., F.F.A. R.C.s., Senior Registrar, Department of Anaesthetics

M. J. ROBINSON, B.M., M.R.C.P., Neonatal Resident, Department of Child M. J. ROBINSON, B.M., M.R.C.P., Neonatal Resident, Department of Child H. GORDON, F.R.C.s., M.R.C.o.G., Senior Lecturer and Honorary Consultant, Department of Obstetrics

J. G. WHITWAM, F.F.A. R.C.S., M.R.C.P., Reader and Honorary Consultant, Department of Anaesthetics

\section{Introduction}

In clinical practice the induction dose of methohexitone for anaesthesia for caesarean section is either related to the patient's weight, and can vary from 0.7 to $1.8 \mathrm{mg} / \mathrm{kg}$ (Lee, 1965) without causing fetal depression, or it is given as a standard dose of $100 \mathrm{mg}$ (Sliom, 1962). Marshall (1964) suggested that up to 120 $\mathrm{mg}$ of methohexitone can be given without significant depression of the infant. The dose of methohexitone for any individual patient should avoid cardiorespiratory depression of the mother and fetus without allowing maternal awareness.

Within the range previously acceptable in clinical practice two induction doses $(1.4 \mathrm{mg} / \mathrm{kg}$ and $1.0 \mathrm{mg} / \mathrm{kg})$ were chosen. A maximum total dose was arbitrarily set at $120 \mathrm{mg}$ and up to this the dosage was based on the predelivery weight since an increase in body weight from any cause will usually increase drug requirement. Recovery of consciousness after a single dose of a short-acting barbiturate, however, is caused mainly by redistribution of the drug into lean body mass (Price, 1960).

\section{Patients and Methods}

SELECTION OF PATIENTS

Twenty-six otherwise healthy patients undergoing elective caesarean section were observed. The indication for operation was disproportion in 21 cases and malpresentation in five. None of the patients was in established labour at the time of operation, the membranes were intact, and a lower segment operation was performed in all cases. The first 12 patients received the higher dose of methohexitone $(1.4 \mathrm{mg} / \mathrm{kg})$ and the subsequent 14 the lower dose $(1.0 \mathrm{mg} / \mathrm{kg})$. The two groups were comparable in respect of maternal age, weight, haemoglobin, gestation period, and the weight of the babies (table I). 